\title{
Pediatri Hemşirelerinin Kendi Mesleklerine İlişkin Metafor Algılarının Değerlendirilmesi
}

\author{
Atiye KARAKUL ${ }^{1}$, (iD) Pınar DOĞAN²， (iD) Beste ÖZGÜVEN ÖZTORNACI ${ }^{3}$
}

'Dr. Öğr. Üyesi, Tarsus Üniversitesi, Sağlık Bilimleri Fakültesi Hemşirelik Bölümü, Hemşirelik Anabilim Dalı, Mersin, Türkiye.

${ }^{2}$ Arş. Gör., İzmir Katip Çelebi Üniversitesi, Sağlık Bilimleri Fakültesi, Çocuk Sağlığı ve Hastalıkları Hemşireliği Anabilim Dalı, İzmir, Türkiye

${ }^{3}$ Dr. Öğr. Üyesi, İzmir Katip Çelebi Üniversitesi, Sağlı Bilimleri Fakültesi, Çocuk Sağlığı ve Hastalıkları Hemşireliği Anabilim Dalı, İzmir, Türkiye

\section{$\ddot{O} z$}

Giriş: Metaforlar, bir kavramın açıklanması ya da anlatılması, kavramın daha kolay anlaşılmasını sağlamaktadır. Metafor odaklı çalışmaların hemşirelikte kullanımı ile mesleğin hemşireler tarafından nasıl algılandığının anlaşılmasını ve mesleğin daha iyi analiz edilmesini kolaylaştırmaktadır. Amaç: S Bu çalışmanın amacı, pediatri hemşirelerinin kendi mesleklerine ilişkin algılarını, metaforlar aracılığıyla ortaya çıkarmaktır. Yöntem: Çalışma nitel araştırma yaklaşımlardan biri olan olgu bilim (fenomenoloji) yaklaşımı kullanılarak yapılmıştır. Araştırmanın örneklemini, Türkiye'de pediatri servislerinde görev yapan 163 hemşire oluşturmuştur. Araştırma verileri Google Form aracılığıyla online olarak, 6 Temmuz-1 Eylül 2020 tarihleri arasında toplanmıştır. Verilerinin toplanmasında kullanılan veri toplama formu, katılımcıların tanıtıcı bilgilerini ve pediatri hemşireliğini nasıl algıladıklarını içeren "Pediatri hemşiresi... gibidir, çünkü..." metafor cümlesinin yer aldığı iki bölümden oluşmaktadır. Elde edilen verilerin değerlendirilmesinde "içerik analizi tekniği” kullanılmıştır. Bulgular: Çalışmaya katılan hemşirelerinin yaş ortalamas $30.81 \pm 7.16$ 'dır (minimum: 21, maksimum: 55). Pediatri hemşirelerinden toplam 51 farklı metafor elde edilmiştir. Elde edilen metaforlar olumlu, olumsuz ve hem olumlu hem olumsuz olmak üzere üç kategoriye ayrılmıştır. Olumlu kategoride üretilen 23 (\%45) metafor; olumsuz kategoride üretilen 14 metafor $(\% 27,5)$ ve hem olumlu hem olumsuz kategoride ise 14 metafor $(\% 27,5)$ yer almaktadır. Katılımcıların 10'unun, pediatri hemşireliği ile ilgili belirtmiş olduğu ifadenin metafor özelliği taşımadığ 1 saptanmıştır. Metaforların gerekçeleri incelendiğinde ise; olumlu kategoride yer alan metaforların, genellikle pediatri hemşireliğinin anne, baba, teyze gibi algılanarak bakım verici yönünün gerekçelendirildiği belirlenmiştir. Olumsuz kategoride yer alan metaforların, ek iş yüklerinin fazla olması, çalışma saatleri ve koşullarına yönelik gerekçeler olduğu görülmüştür. Hem olumlu hem olumsuz kategoride yer alan metaforların gerekçeleri ise pediatri hemşireliğinin çalışma koşullarının yorucu ve yıpratıcı olmasına rağmen çocuklarla birlikte çalışmanın olumlu duyguları ile ilgili olduğu belirlenmiştir. Sonuç: Sonuç olarak, pediatri hemşirelerinin çoğunluğunun olumlu kategoride yer alan metafor ürettiği belirlenmiştir. Pediatri hemşirelerinin mesleki beklentilerinin belirlenmesi, mesleki motivasyonlarının artırılması için çalışma şartlarının iyileştirilmesi önerilebilir.

Anahtar Sözcükler: Pediatri, Hemşire, Metafor.

Abstract

\section{Evaluation of Pediatric Nurses' Metaphor Perceptions Regarding Their Own Professions}

Background: Metaphors make it easier to understand or explain a concept. The use of metaphor-oriented studies in nursing makes it easier to understand how the profession is perceived by nurses and to analyze the profession better. Objective: The aim of this study is to reveal the perceptions of pediatric nurses about their profession through metaphors. Methods: The study was conducted using the phenomenology approach, which is one of the qualitative research approaches. The sample of the study consisted of 163 nurses working in pediatric services in Turkey. Research data were collected online via Google Form between 6 July-1 September 2020.The data collection form used to collect the data consists of two parts with the metaphor sentence "Pediatric nurse is like... because...", which includes introductory information of the participants and how they perceive pediatric nursing. "Content analysis technique" was used in the evaluation of the data obtained. Results: The mean age of the nurses participating in the study was $30.81 \pm 7.16$ (minimum: 21 , maximum: 55). A total of 51 different metaphors were obtained from pediatric nurses. The metaphors obtained were divided into three categories as positive, negative and both positive and negative. 23 metaphors (45\%) produced in the positive category; There are 14 metaphors produced in the negative category (27,5\%) and 14 metaphors in both positive and negative categories (27,5\%). It was determined that the statements of 10 participants about pediatric nursing were not metaphors. When the reasons for the metaphors are examined; It has been determined that metaphors in the positive category are generally perceived as mother, father, aunt and justified the caregiving aspect of pediatric nursing. The metaphors in the negative category were found to be reasons for excessive additional workloads, working hours, and conditions. The reasons for the metaphors in both positive, and negative categories were determined to be related to the positive feelings of working with children, although the working conditions of pediatric nursing were tiring and weary. Conclusion: As a result, it was determined that the majority of pediatric nurses produced metaphors in the positive category. It can be suggested to determine the professional expectations of pediatric nurses, and improve working conditions in order to increase their professional motivation.

Key Words: Pediatric, Nurse, Metaphor.

Geliş Tarihi / Received: 06.05.2021 Kabul Tarihi / Accepted: 30.12.2021

Correspondence Author: Karakul A., Dr. Öğr. Üyesi, Tarsus Üniversitesi, Sağlık Bilimleri Fakültesi Hemşirelik Bölümü, Hemşirelik Anabilim Dalı, Mersin, Türkiye. Telefon: 0(324) 6000033 E-posta:atiyekarakul@gmail.com

Cite This Article: Karakul A, Doğan P, Özgüven Öztornacı B. Pediatri Hemşirelerinin Kendi Mesleklerine İlişkin Metafor Algılarının Değerlendirilmesi.Dokuz Eylül Üniversitesi Hemşirelik Fakültesi Elektronik Dergisi. 2022;15(1): 50-55. 
$\mathbf{P}$ ediatri hemşiresi; doğumdan ergenliğin sonuna kadar yaşamın her alanında büyüme, gelişme, akut ve kronik hastalıklarda bakım verme, çocuk sağlığı için tehdit oluşturan durumların tespit edilmesinde ve çözümünde çocuk, aile ve sağlık ekibiyle iş birliği içinde çalışır. Çocuk hastaya aile merkezli bakım doğrultusunda verilebilecek en iyi sağlık bakımını vermekle yükümlüdür (1). Hemşirelerin kendi meslekleriyle ilgili olumlu yönde görüş ve düşüncesinin olması, dolayısıyla olumlu algıy a sahip olması; bu görev tanımındaki sorumluluklarını yerine getirmedeki performansını, mesleğe uyumunu, verimli bir çalışma yaşamı sürdürmesini ve mesleki gelişimini etkiler (2).

Algı bireylerin duyumlar yoluyla oluşturduğu fiziksel uyaranların, yanında bireyin kendisi ile ve bireyin çevresindeki etmenlerle ilişkili bir tanımlama sürecidir. Algılama sürecindeki en önemli etmen bireydir. Her bireyin aynı kavrama yönelik farklı algısı ve düşüncesi olabilir. Buna bağlı olarak da algısal özellikler farklılık gösterebilir (3). Hemşirelik mesleği algısı, hemşirelik mesleğini yerine getirebilmek için sahip olunması gereken 'mesleki nitelikler' ve hemşirelik mesleğinin toplum içindeki sosyal konumunu gösteren "mesleki statü" kavramlarını içinde barındırmaktadır (4). Bu bağlamda mesleği algılama, bireylerin kendileri, bulundukları çevreyi, hemşireliğin konumu ve hemşirelikteki eylemlerin uygunluğu hakkında hissettiklerini ve düşüncelerini tanımlar (5). Hemşirelerin olumlu mesleki algılarının olması, mesleki yaşantılarında nitelikli hizmet sunumunu etkileyeceği için çok önemlidir (6).

Metafor, bir kavram ile ilgili bireyin aklına gelen ilk kavramsal ifadedir (7). Metaforlar "olayların olușumu ve işleyiși hakkında düşüncelerimizi yapılandıran, yönlendiren ve kontrol eden en güçlü zihinsel araç" olarak tanımlanmaktadır (8). Metaforlar aracılı̆̆ 1 ile bir kavramın açıklanması ya da anlatılması, kavramın daha kolay anlaşılmasını sağlamaktadır (9). Ayrıca bir kavramın nasıl algılandığını da ortaya çıkarmaktadır. Literatürde hemşirelerinin mesleğine ilişsin algılarını ortaya koyan çalışmaların kısıtlı olduğu görülmektedir. Hemşirelerin kendi mesleklerine yönelik metafor algılarının incelendiği bir çalışmaya göre, hemşireler kendi mesleklerini, herkesin istediği her işi verebildiği bir meslek olarak algıladıkları belirlenmiş̧ir (10). Metafor odaklı çalışmaların hemşirelikte kullanımı, mesleğin daha iyi analiz edilmesini kolaylaştırmaktadır. Metaforlar yoluyla pediatri hemşireliğinin nasıl algılandığının anlaşılmasının mesleğin derinlemesine incelenmesine, sorunları konusunda farkındalık yaratılmasına ve mesleğin geliştirilmesine katkı sağlayacağı düşünülmüştür.

\section{Amaç}

Bu çalışmanın amacı, pediatri hemşirelerinin kendi mesleklerine ilişkin algılarını metaforlar aracılığıyla ortaya çıkarmaktır. Araştırma sorusu:

Pediatri hemşirelerinin kendi mesleklerine ilişkin metaforik algıları nelerdir?

\section{Araştırmanın tipi}

\section{Yöntem}

$\mathrm{Bu}$ çalışma, nitel araştırma yaklaşımında olgubilim (fenomenoloji) araştırması olarak planlanmıştır. Olgubilim bireylerin bir olgu veya deneyime yükledikleri anlam veya bu yöndeki algılarını ortaya koymayı hedefler. Olgubilim, bir olayı ya da durumu bireylerin bakış açısına göre tanımlamayı veya anlamayı amaçlar. Bu yöntemde, araştırılan olguyla ilgili olarak ortaya atılan tanımlar kategorilere ayrılmaktadır $(11,12)$. Bu kategoriler, bireylerin ne düşündüklerini ortaya koymaya yardımcı olmaktadır.

\section{Araștırmanın yeri}

Araştırma verileri, Google Formlar aracilığıyla online olarak sosyal medya (instagram ve facebook) üzerinden toplanmıştır. Verilerin toplanmasında kar topu örnekleme yöntemi kullanılmıştır. Hazırlanan anketler araştırmacıların sosyal medya hesaplarından paylaşılmış olup katılımcılara ulaşılmıştır.

\section{Araştrmantn evreni ve örneklemi}

Olgu bilim çalışmalarında örneklem seçimine gidilmemektedir. Her şey o andaki kişi ve grup için geçerlidir. Elde edilen sonuçları, araştırmacı olduğu gibi ortaya koymaktadır (12). Araştırma grubunu, 6 Temmuz-1 Eylül 2020 tarihleri arasında en az bir ay süreyle Türkiye'de pediatri servislerinde görev yapan 163 pediatri hemşiresi oluşturmuştur. Araştırma verilerinde, metaforlar tekrar etmeye başladığı için veri toplama Eylül ayında sonlandırılmıştır. Araştırma verileri online olarak Google Formlar aracılığı ile toplanmıştır. Oluşturulan Google Formda, soruları cevaplamadan diğer soruya geçişe izin verilmemiştir. Bu nedenle çalı̧̧mada bütün anketler eksiksiz doldurulmuş olup, örneklem kaybı olmamıştır.

Dahil edilme kriterleri:

-Araştırmaya katılmaya gönüllü olma

-Türkçe okuyup, yazabilme

-En az bir aydır pediatri servisinde çalışıyor olma

\section{Veri toplama araçlart}

İki bölümden oluşan veri toplama formu araştırmacılar tarafından literatür doğrultusunda geliştirilmiştir $(2,4-6,8,10,11)$. Birinci kısımda pediatri hemşirelerinin tanımlayıcı özelliklerini (yaş, medeni durum, çocuk sayısı, çalışma yılı, pediatri hemşiresi olarak çalışma yılı) içeren beş soru yer almaktadır. İkinci bölümde ise pediatri hemşireliğini nasıl algıladıklarını sorgulayan, "Pediatri hemşiresi... gibidir, çünkü...” metafor cümlesi yer almaktadır $(9,13,14)$.

\section{Verilerin Toplanmast}

Araştırma verileri online platformda toplanmıştır. Google formda ilk önce araştırmanın amacı yazılmış olup, katılımcıların çalışmaya katılımı için onamları alınmıştır. Anket formunda önce tanımlayıcı özelliklere daha sonra katılımcıların pediatri hemşireliğine yönelik metaforik algısını ortaya çıkaracak sorulara yer verilmiştir. Araştırma verilerinin toplanması yaklaşık 3 dakika sürmektedir. 


\section{Verilerin Değerlendirilmesi}

Araştırmadan elde edilen nicel verilerin analizi SPSS 21.0 istatistik paket programında gerçekleştirilmiştir. Çalışmaya katılan pediatri hemşirelerinin tanıtıcı özellikleri sayı ve yüzde dağılımları olarak verilmiştir. Katılımcıların tanıtıcı özellikleri ile metaforların kategorileri arasındaki farklılık ki-kare testi kullanılarak değerlendirilmiştir.

$\mathrm{Bu}$ araştırmada elde edilen nitel verilerin değerlendirilmesinde "içerik analizi tekniği" kullanılmıştır. İçerik analizi, kodlamalar aracılığıyla içerik kategorilerinin oluşturularak özetlenmesidir (15). Elde edilen veriler, verilerin incelenmesi, verilerden anlam çıkarma, verilerdeki anlamı biçimlendirme ve kategoriye ayırma yöntemleri kullanılarak analiz edilmiştir. Gerekçeler doğrultusunda incelenen kategoriler araştırmacılar tarafından ayrıayrı oluşturulmuş olup, nitel araştırmalarda uzman bir kişi tarafından incelenmiştir. Katılımcıların kimliklerini gizlemek adına katılımcılar 1'den 163'e kadar numaralandırılmış ve K harfiyle isimlendirilmiş olup birinci katılımc1 ' $\mathrm{K} 1$ ', ikinci katılımc1 ' $\mathrm{K} 2$ '” şeklinde kodlanmıştır.

Verilerin Incelenmesi: Katılımcıların sorulara verdikleri yanıtlar araştırmacılar tarafından ayrıyrı yazıya aktarılmış ve ortak bir metinde toplanmıştır. 10 katılımcı pediatri hemşireliği ile ilgili metafor üretemediği için analize dahil edilmemiştir. Örnek olarak, pediatri hemşireliği anne gibidir ifadesinde anne metafor olarak kabul edilebilirken; "Pediatri hemşiresi yüreğini acıtmak gibidir" ifadesi metafor içermemektedir.

Verilerden Anlam Çıkarma: Verilen yanıtların incelenmesi sonucu aynı anlamda olan ya da benzer anlam taşıyan ifadeler kategorize edilerek, anlatılmak istenen ifadeye yer verilmiştir. Örneğin, profesyonel annelik sözcükleri "anne" ifadesi şeklinde düzenlenmiştir.

Verilerdeki Anlamı Biçimlendirme: Katılımcıların metaforları gerekçeleri ile yazmış olduğu ankete araştırmacılar herhangi bir yorum yapmamıştır.

Kategoriye Ayırma: Pediatri Hemşirelerinin kendi meslek algısı ile ilgili üretilen metaforlar olumlu, olumsuz ve hem olumlu hem olumsuz olmak üzere üç kategoriye ayrılmıştır (16). Metaforların hem olumlu hem de olumsuz anlamda gerekçelendirildiği belirlenmiş ve her iki kategoride yer almıştır $(17,18)$.

Araştırmanın Etik Yönü

Araştırmanın yürütülebilmesi için bir üniversitenin girişimsel olmayan etik kurulundan (Karar No:820, Tarih:02.07.2020) izin alınmıştır. Anketin ilk sorusuna aydınlatılmış gönüllü olur formu eklenmiş olup, araştırmaya katılan pediatri hemşirelerinden, ankete başlamadan önce onay alınmıştır.

\section{Bulgular}

Çalışmada yer alan pediatri hemşirelerinin tanıtıcı özellikleri Tablo 1'de verilmiştir. Araştırmaya katılan pediatri hemşirelerinin yaş ortalaması $30.81 \pm 7.16$ 'dır (minimum: 21, maksimum:55).

Tablo 1. Pediatri Hemşirelerinin Tanıtıcı Özellikleri

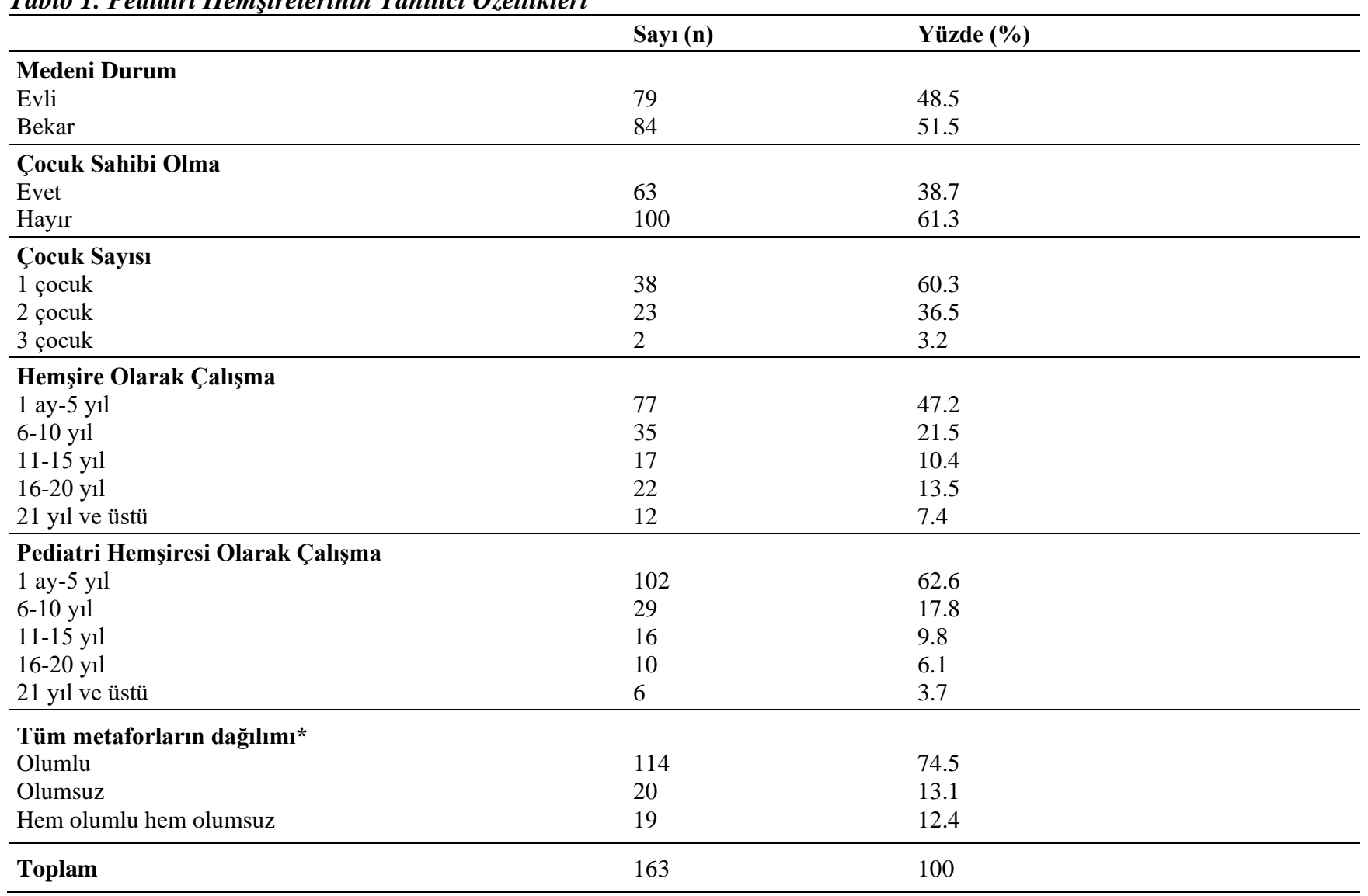

*10 kişi metafor üretemediği için kategorize edilmemiştir.

Araştırmaya dâhil edilen 163 pediatri hemşiresi toplam 51 farklı metafor üretmiştir. Elde edilen metaforlar kategorilere ayrılmıştır. Üretilen bu farklı metaforların \%45'i olumlu (n=23), \%27,5'i olumsuz (n=14) ve \%27,5'i hem olumlu hem de 
olumsuz kategoride ( $\mathrm{n}=14)$ yer almaktadır. Her bir kategori başlı̆̆ altında pediatri hemşirelerinin kendi mesleklerine ilişkin üretmiş olduğu metaforların bildirilme sayısına göre dağılımları Tablo 2'de gösterilmiştir. Pediatri hemşireleri olumlu kategoride en sık "anne"; olumsuz kategoride "robot" metaforlarını üretmiştir. Hem olumlu hem olumsuz kategoride ise en sık üretilen metaforun "mühendislik" olduğu belirlenmiştir.

Tablo 2. Pediatri Hemşirelerinin Kendi Mesleklerine İlişkin Üretmiş Olduğu Metaforlar

\begin{tabular}{|c|c|c|c|c|c|}
\hline Olumlu Metaforlar & $\mathbf{n}^{*}$ & Olumsuz Metaforlar & $\mathbf{n}^{*}$ & $\begin{array}{l}\text { Hem Olumlu Hem Olumsuz } \\
\text { Metaforlar }\end{array}$ & $\mathbf{n}^{*}$ \\
\hline Anne & 57 & Robot & 5 & Mühendislik & 3 \\
\hline Melek & 6 & Kaos & 2 & Atom karınca & 2 \\
\hline Süper kahraman & 6 & Piyon & 2 & En uzun soluklu koşu & 2 \\
\hline Ağaç & 5 & Ahtapot & 1 & Mevsim & 2 \\
\hline Çiçek & 5 & Ask1 & 1 & Amazon kadını & 1 \\
\hline Gökkuşağ1 & 4 & At & 1 & Buzdağ1 & 1 \\
\hline Teyze & 4 & Beyin ameliyat1 & 1 & Cambaz & 1 \\
\hline Can simidi & 3 & Gladyatör & 1 & Çiçek & 1 \\
\hline Cennet & 3 & İşçi arı & 1 & Halka & 1 \\
\hline Dünya & 3 & Modern Kölelik & 1 & İsviçre çakı1sı & 1 \\
\hline Sabır taş1 & 3 & Nankör bir kedi & 1 & Kaktüs & 1 \\
\hline Baba & 2 & Organizatör & 1 & Mart ayı & 1 \\
\hline Güneş & 2 & Taşli yol & 1 & Matruşka & 1 \\
\hline Hayat enerjisi & 2 & Uzaktan kumandalı oyuncak & 1 & Savaşçı & 1 \\
\hline Abla/abi & 1 & & & & \\
\hline Binanın temelindeki kirişler & 1 & & & & \\
\hline Çok yönlü bir işkolu & 1 & & & & \\
\hline Gökyüzü & 1 & & & & \\
\hline İlkbahar & 1 & & & & \\
\hline Kuş & 1 & & & & \\
\hline Kütüphane & 1 & & & & \\
\hline Makina & 1 & & & & \\
\hline Yağmur & 1 & & & & \\
\hline
\end{tabular}

*n sayısı her bir metaforun bildirilme sayısını ifade etmektedir.

Üretilen metaforların kategorileri ile (olumlu, olumsuz, hem olumlu hem olumsuz) katılımcıların demografik özellikleri açısından fark olup olmadığı ki-kare analizi kullanılarak test edilmiş ve herhangi bir farklılık belirlenmemiştir ( $\mathrm{p}>0.05)$. Metaforların gerekçeleri incelendiğinde ise; olumlu kategoride yer alan metaforların, genellikle pediatri hemşireliğinin anne, baba, teyze gibi algılanarak bakım verici yönünün gerekçelendirildiği belirlenmiştir. Katılımcıların olumlu metaforlara yönelik belirttiği gerekçeler aşağıdaki gibidir.

\section{Olumlu algilara yönelik örnek ifadeler}

"Duvarların değil hayatlarin temelini inşa edersin." (K12)

"Bakım verdiğimiz çocuğa en verimli hizmeti verebilmek için onun annesi gibi düşünmek gereklidir. Bu sayede onu her anlamda, fiziksel ve mental olarak en iyi sağlık durumuna getirmek için en verimli şekilde bakım verebiliriz.” (K129)

Olumsuz kategoride yer alan metaforların gerekçeleri incelendiğinde ise, ek iş yüklerinin fazla olması, çalışma saatleri ve koşullarına yönelik gerekçeler olduğu görülmüştür.

Olumsuz algılara yönelik örnek ifadeler

"Yorucu, ara bulucu, her şeyi toparlayıcl, sürekli çok verimli olması beklenilen bir meslek" (K64)

"Her şeye koşan, yorulmayan-dinlenemeyen, zamansız çalıştığı için" (K60)

Hem olumlu hem olumsuz kategoride yer alan metaforların pediatri hemşireliğinin çalışma koşullarının yorucu ve yıpratıcı olmasına rağmen çocuklarla birlikte çalışmanın olumlu duyguları ile ilgili olduğu belirlenmiştir. Katılımcıların hem olumlu hem de olumsuz metaforlara yönelik belirttiği gerekçeler aşağıdaki gibidir.

Hem olumlu hem olumsuz algılara yönelik örnek ifadeler

"Hem heyecan verici hem riskli hem de ilginç bir deneyimdir." (K57)

"Bazen bahar olur içinizi ısıtır küçücük ama kocaman sevgi dolu yürekleri bazen de sonbahar gibidir içinizi acı hüzün kaplar tedaviye yanıt alamadıklarını gördükçe" (K91) 


\section{Tartışma}

$\mathrm{Bu}$ çalışma, pediatri hemşirelerinin mesleklerine ilişkin algılarının, metaforlar aracılığıyla ortaya çıkarılması amacıyla yapılmıştır. Metaforlar kişilerin duygu ve düşüncelerini betimlemek ve algılarını ortaya çıkarmak için kullanılan yöntemlerden biridir (19). Çalışmada pediatri hemşirelerinin çoğunluğunun kendi mesleklerine ilişkin olumlu metafor ürettiği belirlenmiştir. Bu çalışmada büyük oranda "anne" metaforu olmak üzere "baba, çiçek, güneş, gökkuşağı" gibi olumlu kategoride yer alan metaforlar, pediatri hemşireliğinin doğasını oluşturan şefkat gösterme yönünü ortaya koymaktadır. Roney ve Acri (2018) çalışmasında, pediatri hemşirelerinin şefkat ve merhamet düzeyinin ortalamanın üzerinde olduğunu belirtmiştir (20). Şefkatli bakım sağlama ve yardım etme, hastanın sağlığının optimal seviyeye çıkarılması ve klinikten sağlıklı bir şekilde taburcu olması özellikle çocuk hastanın bakımında ön plana çıkmaktadır. Bu nedenle çalışmada elde edilen bu metaforlar pediatri hemşirelerinin bakım algısının yüksek olduğunu göstermektedir. Kase, Waldman ve Weintraub (2019) çalışmasında, çocuk hastalara etkili şefkatli bakım sağlamak için, pediatri hemşirelerinin fiziksel yorgunluk ve duygusal tükenme gibi faktörlere karşı dikkatli olması gerektiğini belirtmiştir (21). Literatürdede pediatri kliniklerinde çalışan hemşirelerin bakım davranışları algılarının yüksek olduğu bildirilmiştir $(21,22)$. Ayrıca pediatri hemşirelerinin diğer kliniklerde çalışan hemşirelere göre işlerinden daha memnun olduğu belirtilmiştir (20).

Yapılan bir çalışmada hemşirelerin çoğunluğunun mesleklerine ilişkin olumsuz metaforlar sunduğu belirtilmiştir (10). Yapılan bu çalışmada olumlu metaforların çok olmasına rağmen olumsuz metaforlar da bulunmaktadır. Pediatri hemşireleri "ahtapot, nankör bir kedi,robot, modern kölelik, uzaktan kumandalı oyuncak" gibi olumsuz metaforlar üretmiştir. Olumsuz kategoride yer alan metaforların çoğunluğunun gerekçesinde pediatri hemşireliğinin yoğun ve stresli çalışma koşulları ve iş yükünün fazla olması vurgulanmaktadır. Benzer şekilde Kale ve Çiçek (2015) çalışmasında, hemşirelerin çoğunluğunun çalışma şartlarının ağırlığı, zorluğu ve hemşirelik mesleğinin görev tanımının belirsiz olmasını kapsayan olumsuz metaforlar ürettiklerini bildirmişlerdir. Aynı zamanda ifade edilen gerekçelere bağlı olarak hemşirelerin çoğunluğunun olumsuz ifadelere yer verdikleri görülmüştür (10). Buckley ve ark. (2020) yapmış oldukları sistematik derlemede de pediatri hemşirelerinin tükenmişlik düzeylerinin yüksek olduğu görülmüştür. Ayrıca çalışma ortamı ve çalışma koşullarının pediatri hemşirelerinde tükenmişliği etkileyen bir dizi faktör olarak tanımlanmıştır (23). Yılmaz, Şen ve Demirkaya (2014) yapmış oldukları çalışmada hemşirelerin büyük çoğunluğu $(\% 78,5)$ hemşireliği yıpratıcı bir meslek olarak gördüklerini belirtmiştir (24).

Çalışmada on dört metafor ise hem olumlu hem olumsuz kategoride değerlendirilmiştir. Bu kategoride "amazon kadını, atom karınca, buzdağı, cambaz, savaşçı” gibi metaforların olduğu görülmüştür. Hem olumlu hem olumsuz kategoride değerlendirilen metaforlar ile pediatri hemşireliğinin riskli, acı dolu, yorucu ve yıpratıcı olmasının yanında çocuklar ile birlikte çalışmanın sevgi, masumluk, samimiyet duygularını içeren olumlu yönününde bulunduğunu ifade etmektedir. Yapılan bir çalışmada hemşireliğin kutsal olduğu anacak hak ettiği değeri görememesi gerekçesiyle, dokuz metaforun hem olumlu hem olumsuz kategoride değerlendirildiği bildirilmiştir (10).

\section{Kisıtlılıklar}

Çalışma sadece, sosyodemografik sorular ve "Pediatri hemşiresi... gibidir, çünkü..." metafor cümlesi ile sınırlıdır. Çalışma verileri pandemi döneminde toplanmıştır. Dolayısıyla hemşirelerin pandemi döneminde yoğun ve zor çalışma koşullarının olması nedeniyle, pediatri hemşirelerinin ürettiği metaforların bu durumdan etkilenebileceği düşünülmektedir. Çalışma verilerinin online olarak toplanması da çalışmanın bir diğer sınırlılığını oluşturmaktadır.

\section{Sonuçların Uygulamada Kullanımı}

Pediatri hemşirelerinin çoğunluğunun kendi mesleklerine ilişkin olumlu algı içeren metafor ürettikleri sonucuna ulaşılmıştır. Pediatri hemşirelerinin mesleklerine ilişkin metaforların belirlenmesi mesleki farkındalığın oluşması ve sorunların analiz edilmesine katkı sağlayacağı düşünülmektedir. Çalışma sonuçları doğrultusunda;

-Pediatri hemşirelerinin mesleki beklentilerinin belirlenmesi,

-Mesleki motivasyonlarının artırılması için çalışma şartlarının iyileştirilmesi,

-Pediatri kliniklerinde çalışma ortamının iyileştirilmesi önerilebilir.

\section{Bilgilendirme}

Yazarların araştırmadaki katkıları: fikir A.K.; tasarım A.K.,; verilerin toplanması: A.K., P.D., B.Ö.Ö.; verilerin analizi A.K., P.D., B.Ö.Ö.; literatür tarama ve makale yazımı A.K., P.D., B.Ö.Ö.; eleştirel değerlendirme A.K. tarafından yapılmıştır. Araştırmanın yapılabilmesi için 02.07.2020 tarih ve 820 sayı numarası ile bir üniversitenin girişimsel olmayan etik kurulundan izin alınmıştır. Araştırmaya katılan pediatri hemşirelerinden onay alınmıştır. Bütün yazarlar bu makalenin son halini onaylamaktadır. Araştırmaya katılım gösteren pediatri hemşirelerine teşekkür ederiz. Yazarlar arasında herhangi bir çıkar çatışması yoktur. Bu çalışmada finansal destek alınmamıştır. Araştırmanın bütçesi araştırmacılar tarafından karşılanmıştır. 


\section{Kaynaklar}

1. Conk Z, Başbakkal Z, Yardımcı F. Çocuk sağlığına genel bakış. In: Conk Z, Başbakkal Z, Yılmaz H, Bolışık B, editörler. Pediatri Hemşireliği. 1st ed. Ankara: Akademisyen Kitapevi: 2013:35-41.

2. Özmen D, Çetinkaya A. Hemşirelik son sınıf öğrencilerinin mesleki algılarına yönelik nitel bir çalışma. Hemşirelikte Araştırma Geliştirme Dergisi 2016;18(1):40-52.

3. Erişti SD, Uluuysal B, Dindar M. Görsel algı kuramlarına dayalı etkileşimli bir öğretim ortamı tasarımı ve ortama ilişkin öğrenci görüşleri. Anadolu Üniversitesi Eğitim Bilimleri Enstitüsü Dergisi 2013;3(1):47-66.

4. Eşer İ, Khorshid L, Denat Y. Hemşirelik mesleğini algılamada ilk klinik uygulamanın etkisi. Ege Üniversitesi Hemşirelik Yüksek Okulu Dergisi 2008;24(1):15-26.

5. Yücel ŞÇ, Güler EK, Eşer İ, Khorshid L. İki farklı eğitim sistemi ile öğrenim gören hemşirelik son sınıf öğrencilerinin hemşirelik mesleğini algılama durumlarının karşılaştırılması. Ege Üniversitesi Hemşirelik Yüksekokulu Dergisi 2011;27 (3):18.

6. Dimitriadou M, Papastavrou E, Efstathiou G, Theodorou M. Baccalaureate nursing students' perceptions of learning and supervision in the clinical environment. Nursing and Health Sciences 2015;17(2):236-42.

7. Eraslan L. Sosyolojik metaforlar. Akademik Bakış Dergisi.2011;27:1-22.

8. Saban A. Giriş düzeyindeki sınıf öğretmeni adaylarının öğretmen kavramına ilişkin ileri sürdükleri metaforlar. Türk Eğitim Bilimleri Dergisi 2004;2:135-155.

9. Demir C, Yıldırım ÖK. Türkçede metaforlar ve metaforik anlatımlar. Afyon Kocatepe Üniversitesi Sosyal Bilimler Dergisi 2019;21(4):1085-1096.

10. Limon İ, Durnalı M. Doktora öğrencilerinin doktora eğitimi ve öğretim üyelerine yönelik metaforik algıları. Sakarya University Journal of Education 2018;8(1):26-40.

11. Kale E, Çiçek Ü. Hemşirelerin kendi mesleklerine ilişkin metafor algıları. Sağlık ve Hemşirelik Yönetimi Dergisi 2015; 2(3):142-151.

12. Kocabıyık OO. Olgubilim ve gömülü kuram: Bazı özellikler açısından karşılaştırma. Trakya Üniversitesi Eğitim Fakültesi Dergisi 2016;6(1):55-66.

13. Sönmez V, Alacapınar FG. Örneklendirilmiş bilimsel araştırma yöntemleri. 5th ed. Ankara: Anı Yayıncılık; $2017: 311$.

14. Temel ZF, Kanat K, Kaynak Ekici KB, Canberi F. Hastaneye yatma deneyimi olan ve olmayan 5-6 yaş çocuklarının doktor, hemşire ve hastane algılarının incelenmesi. Türkiye Sosyal Araştırmalar Dergisi 2018; 22:251-278.

15. Küçük S, Demir K, Uludaşdemir D. Hastanede yatan yedi-on yedi yaş grubundaki çocuk ve ergenlerin hemşire algısına ilişkin metaforların belirlenmesi. HEAD. 2020;17(1):40-45.

16. Eraslan L. Sosyolojik metaforlar, Akademik Bakış Dergisi 2011;27:1-22.

17. Yüzer S, Alıcı D, Yiğit R. Pediatri hemşirelerinin rolleri ve fonksiyonları ölçeğinin uygulanmasının geliştirilmesi: Güvenirliği ve geçerliliği. Atatürk Üniversitesi Hemşirelik Yüksekokulu Dergisi 2008;11(4):19- 29.

18. Çulha Özbaş B, Aktekin S. Tarih öğretmen adaylarının tarih öğretmenliğine ilişkin inançlarının metafor analizi yoluyla incelenmesi. Eğitimde Kuram ve Uygulama 2013;9(3):211-28.

19. Zembat R, Tunçeli İ, Akşin E. Okul öncesi öğretmen adaylarının “okul yöneticisi” kavramına ilişkin algılarına yönelik metafor çalışması. Hacettepe Üniversitesi Sağlık Bilimleri Fakültesi Dergisi 2015;2(1):446- 459.

20. Roney LN, Acri MC. The cost of caring: an exploration of compassion fatigue, compassion satisfaction, and job satisfaction in pediatric nurses. Journal of Pediatric Nursing 2018; 40:74-80.

21. Kase SM, Waldman ED, Weintraub AS. A cross-sectional pilot study of compassion fatigue, burnout, and compassion satisfaction in pediatric palliative care providers in the United States. Palliative Supportive Care 2019;17(3): 269-275.

22. Zengin M, Yayan EH, Yıldırım N, Elif A, Avşar Ö, Mamiş E. Pediatri hemşirelerinin profesyonel değerlerinin profesyonel tutumlarına etkisi. Sağlık Bilimleri ve Meslekleri Dergisi 2018;5(3):316-323.

23. Buckley L, Berta W, Cleverley K, Medeiros C, Widger K. What is known about paediatric nurse burnout: a scoping review. Human Resources for Health 2020;18(1):1-23.

24. Yılmaz TF, Şen TH, Demirkaya F. Hemşirelerin ve ebelerin mesleklerini algılama biçimleri ve gelecekten beklentileri. Sağlık ve Hemşirelik Yönetimi Dergisi 2014;1(3):130-139. 